\title{
Long-term effects of surgically implanted telemetry tags on the nutritional physiology and condition of wild freshwater fish
}

\author{
Michelle Caputo ${ }^{1,2}$, Constance M. O'Connor ${ }^{1, *}{ }^{\prime}$, Caleb T. Hasler ${ }^{1}$, \\ Kyle C. Hanson ${ }^{1}$, Steven J. Cooke ${ }^{1,2}$ \\ ${ }^{1}$ Fish Ecology and Conservation Physiology Laboratory, Ottawa-Carleton Institute of Biology, and \\ ${ }^{2}$ Institute of Environmental Science, Carleton University, 1125 Colonel By Drive, Ottawa, Ontario K1S 5B6, Canada
}

\begin{abstract}
Little is known about the long-term consequences of surgically implanted telemetry devices on wild fish, as they are rarely recaptured. We used wild largemouth bass Micropterus salmoides as a model to evaluate the long-term impacts of telemetry devices on fish physiology and nutritional condition in a closed freshwater lake where recapture rates were reasonably high. Between 2003 and 2005, 68 fish were surgically implanted with acoustic telemetry devices. Between 2005 and 2008, 17 of the tagged fish were recaptured after carrying a transmitter for 335 to 1402 d. Incision sites were examined, and individuals were non-lethally sampled for blood and measured prior to release. Plasma samples were analysed, and physiological measures of stress (glucose, $\mathrm{Na}^{+}$, $\mathrm{Cl}^{-}, \mathrm{K}^{+}$), tissue damage (aspartate aminotransferase), and nutritional status $\left(\mathrm{Ca}^{++}, \mathrm{Mg}^{+}\right.$, phosphorus, total protein, triglycerides, cholesterol) were compared between fish carrying transmitters and temporally- and size-matched controls. Of the 17 recaptured fish, 3 retained at least 1 of the absorbable monofilament sutures and showed localised signs of inflammation and infection despite an elapsed time of 362 d post surgery. Five individuals showed signs of pressure necrosis at the incision site despite the fact that the transmitters averaged only $1.89 \%$ (range: 0.84 to $3.59 \%$ ) of the body mass. There was no difference in any physiological parameter measured between the 2 groups, or within the telemetered fish, in relation to days since tagging or condition of the incision site. In summary, transmitter implantation was not correlated with any long-term change in any of the physiological parameters investigated. However, there is opportunity for additional research to optimise surgical techniques, guidelines on transmitter mass to body mass ratios, and choice of suture material to enhance the healing and long-term welfare of tagged fish.
\end{abstract}

KEY WORDS: Telemetry $\cdot$ Fish $\cdot$ Surgical techniques $\cdot$ Nutritional physiology $\cdot$ Body condition

\section{INTRODUCTION}

Telemetry has become a common tool in fisheries research, contributing to the conservation and management of many different fish species by providing important information on fish distribution (e.g. migration patterns and habitat selection), energy use (e.g. activity), and behaviour (see Lucas \& Baras 2000, Cooke et al. 2004). A fundamental tenet of telemetry research is that the attachment procedure or the presence of the transmitter does not alter the behaviour, condition, or survival of the tagged organism, and the data obtained from the tagged individual are therefore representative of the population as a whole (Bridger \& Booth 2003). Of late, this tenet has become more important as attention to fish welfare (Mulcahy 2003, Huntingford et al. 2006) and the use of telemetry devices to study endangered fish (see Cooke 2008) have increased. Although there are multiple attachment techniques, intraperitoneal surgical implantation is generally regarded as the most appropriate approach for longer-term studies (Bridger \& Booth 
2003) and has benefited from controlled research comparing different surgical techniques (Bridger \& Booth 2003, Mulcahy 2003, Wagner \& Cooke 2005). This research has revealed an immediate stress response to surgery, handling, and anaesthesia, but after approximately 8 to $10 \mathrm{~h}$, the stress levels tend to return to normal (Jepsen et al. 2001, Close et al. 2003, Lower et al. 2005, Feldhaus et al. 2008). Furthermore, laboratory studies have examined the consequences of transmitter implantation on growth, swimming performance, and survival of intervals ranging from days to weeks (e.g. Lucas 1989, Moore et al. 1990, Adams et al. 1998, Martinelli et al. 1998; reviewed by Bridger \& Booth 2003). Comparatively little is known about the longerterm consequences of intraperitoneal telemetry transmitters (Tyus 1988), with a deficit of research conducted on unrestrained wild fish. The few longer-term field studies that have been published tended to focus on transmitter retention and fish growth and survival (Jepsen \& Aarestrup 1999, Jepsen 2003, Jepsen et al. 2008). Such field-based validation studies are critical, as laboratory studies may not reflect the challenges (e.g. avoiding predators, securing food, and resisting disease) that are inherent in the natural environments where most telemetry studies are conducted.

The purpose of this study was to determine the longterm physiological effects of transmitter devices on fish. The study was conducted in a small freshwater research lake in eastern Ontario, Canada, that is equipped with a whole-lake acoustic telemetry array (Cooke et al. 2005a, Hasler et al. 2007, Hanson et al. 2007a,b). Largemouth bass Micropterus salmoides have been intraperitoneally tagged with acoustic transmitters since 2003 and recaptured by rod-andreel angling since 2005 (Hanson et al. 2007b). These recaptures have enabled examination of the incision site, measurement of individuals, and the non-lethal collection of blood samples. Using the blood samples, we compared the nutritional physiology and condition of telemetry-tagged fish to temporally- and sizematched controls. Physiological indicators were chosen to reflect the overall condition of fish, with attention to indicators of the secondary stress response (glucose, $\mathrm{Na}^{+}, \mathrm{Cl}^{-}, \mathrm{K}^{+}$; Wendelaar-Bonga 1997), tissue damage (aspartate aminotransferase; Wagner \& Congleton 2004), and nutritional status $\left(\mathrm{Ca}^{++}, \mathrm{Mg}^{+}\right.$, phosphorus, total protein, triglycerides, cholesterol; Wagner \& Congleton 2004, Hanson \& Cooke in press). We used these sensitive physiological indicators based on the premise that if the devices or the surgical procedure were causing stress, disease/infection, or reductions in feeding or digestive function over the long term, we would be able to detect a significant difference relative to size- and temporally-matched controls. Additionally, the relationships between time since tag- ging, condition of the incision site, and physiological indicators were evaluated. Collectively, this study provides the first long-term assessment of the nutritional physiology of wild fish implanted with intraperitoneal telemetry devices in the laboratory or the field.

\section{MATERIALS AND METHODS}

Study site. Warner Lake is a small (approximately 8.2 ha surface area) private research lake in eastern Ontario ( $\left.44^{\circ} 31^{\prime} \mathrm{N}, 76^{\circ} 22^{\prime} \mathrm{W}\right)$. In November of 2003, the lake was equipped with a code division multiple access technology (CDMA)-based acoustic telemetry array (Cooke et al. 2005a, Hanson et al. 2007a,b). Warner Lake is a closed system, and has been used by researchers to study largemouth bass population dynamics since 1996 using passive integrated transponder (PIT) tags (Biomark) for long-term monitoring. Largemouth bass are the largest species, apex predator, and the only tagged species of fish in the lake.

Transmitter implantation. Between 2003 and 2005, 68 adult largemouth bass (all $>28 \mathrm{~cm}$ total length) were implanted with acoustic telemetry devices (see Hanson et al. 2007b). The transmitters were embedded within a polyethylene sleeve, with a bio-compatible epoxy on one end, with no antenna. Fish were implanted with acoustic telemetry devices on 3 separate occasions: October 2003, October 2004, and October 2005 (see Hanson et al. 2007b for details). The size of the transmitters used varied among the different years depending upon the sensors aboard the device and other settings that influenced battery size (see Hanson et al. $2007 \mathrm{~b}$ for details on all of the devices). We attempted to abide by the ' $2 \%$ rule' (that the mass of the device should be no more than $2 \%$ of the body mass of the fish; Winter 1983, Brown et al. 1999), although on occasion we violated it slightly (largest deviation was $3.59 \%$ ratio of transmitter mass in air to fish mass in air). More importantly, prior to implanting an individual and again during surgery, we determined that there was adequate room within the abdominal cavity for the device such that there would not be any pressure on viscera or the body wall that could lead to problems with feeding or pressure necrosis. For all occasions, fish were implanted using standard surgical procedures (see Cooke et al. 2003). Briefly, fish were anaesthetised by placing individuals in an induction bath containing $60 \mathrm{mg} \mathrm{l}^{-1}$ clove oil emulsified in ethanol. After loss of equilibrium (5 min), total length measurements were taken, and fish were placed on a foam surgery table. During the surgery, the gills were continuously irrigated with recirculating water containing a maintenance dose $\left(20 \mathrm{mg} \mathrm{l}^{-1}\right)$ of clove oil 
in ethanol. A small incision $(\sim 1.5 \mathrm{~cm})$ was made on the ventral side of the fish using a sterilised scalpel. An acoustic transmitter was then inserted into the intraperitoneal cavity, and the incision was closed using 3 independent absorbable monofilament PDS II sutures (size 3/0, FSL needle, Ethicon). Measures were taken to ensure a near-sterile environment, including the use of surgical gloves and disinfection of all surgical instruments using iodine. Additionally, all fish were individually identified with PIT tags. After surgery, the fish were placed in a recovery bath and were released upon regaining equilibrium (10 to $20 \mathrm{~min}$ ). Experienced surgeons performed all implants (Cooke et al. 2003), no immediate (i.e. <1 h) mortality was observed, and all fish were released following the surgeries.

Recapture data collection. Largemouth bass were recaptured by rod-and-reel during 4 separate re-sampling periods: September 2006, June 2007, August 2007, and October 2007. Fish were landed within $30 \mathrm{~s}$ using standard heavy action angling gear, placed in a foam-lined trough filled with fresh lake water, and sampled for blood within 1 min of capture using the caudal puncture technique, with lithium-heparinised collection tubes (B.D. Vacutainer). Telemetered fish were identified using PIT tags. Prior to release, we examined the ventral surface of the fish and (when detectable) made observations of the incision site. We examined 4 characteristics: (1) whether the incision was fully closed; (2) presence of unabsorbed sutures; (3) incidence of infection at the incision site; and (4) any evidence of pressure necrosis. We paired each telemetered fish with a size-matched non-telemetered fish captured on the same date. Whole blood from both telemetered and non-telemetered fish was stored in an ice-water slurry for no more than 30 min after collection, and the plasma was then separated by centrifuging at $10000 \times g$ for $5 \mathrm{~min}$ (Compact II Centrifuge, Clay Adams). Plasma samples were transported to a $-80^{\circ} \mathrm{C}$ freezer in liquid nitrogen for storage until analysis.

Biochemical analyses. Plasma samples were analysed by Vita-Tech Canada for a variety of biochemical factors that indicate stress physiology, tissue damage, and nutritional status. Analyses of enzyme activity of aspartate aminotransferase and concentrations of glucose, $\mathrm{Cl}^{-}, \mathrm{Na}^{+}, \mathrm{K}^{+}, \mathrm{Ca}^{++}, \mathrm{Mg}^{+}$, phosphorus, total protein, triglycerides, and cholesterol were conducted on a Roche Hitachi 917 analyser and based upon the International Federation of Clinical Chemistry and Laboratory Medicine standard reference model using the procedural guidelines for standardisation and quality assurance set out by the Veterinary Laboratory Association Quality Assurance Program, New York State Department of Health, College of American Pathologists, and the Canadian Food Inspection Agency External Proficiency Panel.
Statistical analyses. All physiological indicators were tested for normal distribution using goodnessof-fit tests, and for equality of variances using Levene's test (Zar 1999). Glucose, chloride, aspartate aminotransferase, and triglycerides did not meet the assumptions of normality and were $\log _{10}$ transformed prior to further analyses (non-transformed data are presented in the tables). All physiological parameters and growth rates were compared between telemetered and matched non-telemetered controls using paired $t$-tests, and between telemetered fish in 'good' and 'poor' condition using simple t-tests (Zar 1999). To test whether there was a relationship between any of the physiological parameters and time since tagging, or tag mass as a percentage of fish body mass at the time of tagging, least squares linear regression analysis was conducted using data from only the telemetered fish to determine if the slope differed from 0 (Zar 1999). Bonferroni corrections for multiple tests were applied to both the paired tests and the regressions, generating a significance of $\alpha=0.0045$. All statistical analyses were performed using JMP v.7.0.1 (SAS Institute).

\section{RESULTS}

In total, we recaptured 17 telemetered fish (25\% of the 68 transmitter-implanted individuals). All wounds were fully closed, and for 5 (29\%) of the fish, the incision site was not visually detectable (we had to rely on PIT tag identification to determine that fish were indeed carrying a telemetry device). For the fish where the incision was evident, the condition of the incision site varied extensively. Five (29\%) of the fish had wellhealed scars that were yellow or white in colour, with deformed scales or no scales over the incision. Three fish $(18 \%)$ still had sutures present, with associated redness and signs of infection localised to the incision site. Although there was no evidence of transmitter expulsion in fish that were recaptured, 5 (29\%) individuals showed signs of pressure necrosis and bulging at or near the incision site (Table 1). The ratio of transmitter mass to body mass of fish was $1.88 \%$ for fish with pressure necrosis (range: $1.23 \%$ to $2.97 \%$ ) and $1.94 \%$ for fish without pressure necrosis (range: $0.84 \%$ to $3.59 \%$ ).

Plasma samples were obtained from 14 temporallyand size-matched pairs of telemetered and nontelemetered largemouth bass. When comparing the physiological parameters between telemetered and non-telemetered fish, there were no significant differences in any of the variables examined (Table 2). When comparing the physiological parameters between telemetered fish in 'good' condition $(\mathrm{n}=8$; 
Table 1. Micropterus salmoides. incision characteristics in recaptured fish that were previously implanted with telemetry transmitters. Data are sorted by tag mass as a percentage of body mass at the time of tagging in ascending order

\begin{tabular}{|lcccccc|}
\hline $\begin{array}{l}\text { Fish } \\
\text { ID }\end{array}$ & $\begin{array}{c}\text { Days since } \\
\text { tagging }\end{array}$ & $\begin{array}{c}\text { Tag as } \\
\text { \% body mass }\end{array}$ & $\begin{array}{c}\text { Wound } \\
\text { open }\end{array}$ & $\begin{array}{c}\text { Sutures } \\
\text { present }\end{array}$ & $\begin{array}{c}\text { Infection } \\
\text { present }\end{array}$ & $\begin{array}{c}\text { Pressure } \\
\text { necrosis }\end{array}$ \\
\hline 1 & 1402 & 0.84 & No & No & No & No \\
2 & 722 & 1.17 & No & No & No & No \\
3 & 388 & 1.23 & No & No & No & Yes \\
4 & 680 & 1.29 & No & No & No & No \\
5 & 680 & 1.29 & No & No & No & No \\
6 & 680 & 1.29 & No & No & No & No \\
7 & 335 & 1.36 & No & No & No & No \\
8 & 680 & 1.51 & No & Yes & Yes & No \\
9 & 733 & 1.53 & No & Yes & Yes & Yes \\
10 & 680 & 1.53 & No & No & No & Yes \\
11 & 707 & 2.14 & No & No & No & Yes \\
12 & 362 & 2.40 & No & Yes & Yes & No \\
13 & 1042 & 2.44 & No & No & No & No \\
14 & 1042 & 2.97 & No & No & No & Yes \\
15 & 1095 & 2.97 & No & No & No & No \\
16 & 707 & 3.12 & No & No & No & No \\
17 & 1095 & 3.59 & No & No & No & No \\
& Summary & & $0 \%$ & $17.6 \%$ & $17.6 \%$ & $29.4 \%$ \\
\hline
\end{tabular}

\section{DISCUSSION}

Our results indicate that there are no detectable long-term physiological consequences of transmitter implantation to fish nutrition or stress as measured by the variables included in the current study. However, the observation of some retained sutures and infections suggests that improving surgical technique and choice of suture material is necessary to minimise longterm costs of telemetry devices for animals that are implanted with them. Moreover, pressure necrosis was evident even when we generally abided by the $2 \%$ rule, suggesting that longerterm studies may require different criteria for transmitter size to fish body size ratios.

\section{Physiology}

wound closed, no sutures, no infection, no pressure necrosis; Table 1) and the telemetered fish in 'poor' condition ( $\mathrm{n}=6$; 1 or more unabsorbed sutures, infection, pressure necrosis; Table 1), there were also no significant differences in any of the variables examined (Table 3). Furthermore, there were no significant relationships in the telemetered fish between days since tagging and any of the physiological variables, or between tag mass as a \% of body mass at the time of tagging, and any of the physiological variables (Table 4).
Levels of glucose, chloride, sodium, and potassium are indicative of stress from handling or anaesthesia, and have been used in many short-term studies of the effects of transmitter devices on fish (Jepsen et al. 2001, Close et al. 2003, Lower et al. 2005, Feldhaus et al. 2008). Since there was no significant difference between the telemetered and non-telemetered fish in any of these indicators, it is clear that there was no latent stress response from surgery, handling, and anaesthesia (Wendelaar-Bonga 1997). This is not unexpected, as fish normally recover from this type of stress

Table 2. Micropterus salmoides. Comparison of plasma physiological indicators between individuals implanted with telemetry transmitters $(n=14)$ and paired temporally- and size-matched controls $(n=14)$ using paired $t$-tests. All units reported are in $\mathrm{mmol} \mathrm{l}^{-1}$ except aspartate aminotransferase, which is reported in International Units $\mathrm{l}^{-1}$. No significant differences were found for any parameters following Bonferroni corrections $(\alpha=0.0045)$

\begin{tabular}{|c|c|c|c|c|c|}
\hline \multirow{2}{*}{$\begin{array}{l}\text { Physiological } \\
\text { parameter }\end{array}$} & \multicolumn{2}{|c|}{$\longrightarrow$ Mean } & \multirow[b]{2}{*}{ Mean difference \pm SE } & \multirow{2}{*}{$\begin{array}{c}\text { Statistics } \\
t\end{array}$} & \multirow[b]{2}{*}{$\mathrm{p}$} \\
\hline & Telemetered & Non-telemetered & & & \\
\hline Glucose & 3.06 & 3.21 & $0.15 \pm 0.25$ & 0.30 & 0.77 \\
\hline Chloride & 114.40 & 117.20 & $2.80 \pm 5.08$ & 0.38 & 0.71 \\
\hline Sodium & 171.33 & 173.67 & $2.33 \pm 2.90$ & 0.80 & 0.43 \\
\hline Potassium & 2.04 & 3.24 & $1.20 \pm 0.44$ & 2.71 & 0.02 \\
\hline $\begin{array}{l}\text { Aspartate } \\
\text { aminotransferase }\end{array}$ & 27.73 & 40.73 & $13.26 \pm 13.25$ & 0.39 & 0.70 \\
\hline Calcium & 3.53 & 3.51 & $0.022 \pm 0.15$ & 0.14 & 0.89 \\
\hline Magnesium & 1.45 & 1.48 & $0.02 \pm 0.05$ & 0.46 & 0.65 \\
\hline Phosphorus & 2.49 & 2.57 & $0.08 \pm 0.18$ & 0.45 & 0.66 \\
\hline Total protein & 44.40 & 42.27 & $2.13 \pm 1.68$ & 1.27 & 0.23 \\
\hline Triglycerides & 2.48 & 2.27 & $0.21 \pm 0.46$ & 0.80 & 0.43 \\
\hline Cholesterol & 11.43 & 11.97 & $0.53 \pm 0.77$ & 0.69 & 0.50 \\
\hline
\end{tabular}


Table 3. Micropterus salmoides. Comparison of plasma physiological indicators between recaptured individuals with previous telemetry incisions in 'good' condition $(\mathrm{n}=8)$, and individuals with previous telemetry incisions in 'poor' condition $(\mathrm{n}=6)$ using simple $t$-tests. All units reported are in $\mathrm{mmol} \mathrm{l}^{-1}$ except aspartate aminotransferase, which is reported in International Units $\mathrm{l}^{-1}$. No significant differences were found for any parameters following Bonferroni corrections $(\alpha=0.0045)$

\begin{tabular}{|lrrrrr|}
\hline \multirow{2}{*}{$\begin{array}{l}\text { Physiological } \\
\text { parameter }\end{array}$} & \multicolumn{2}{c}{ Mean \pm SE } & \multicolumn{2}{c|}{ Statistics } \\
\cline { 2 - 4 } & 'Good' condition & 'Poor' condition & & $t$ & $\mathrm{p}$ \\
\hline Glucose & $2.98 \pm 0.21$ & $2.83 \pm 0.22$ & 0.42 & 0.68 \\
Chloride & $115.25 \pm 5.77$ & $114.67 \pm 1.91$ & 0.07 & 0.95 \\
Sodium & $173.00 \pm 2.60$ & $170.50 \pm 2.33$ & 0.69 & 0.50 \\
Potassium & $1.93 \pm 0.31$ & $2.08 \pm 0.64$ & 0.24 & 0.81 \\
Aspartate & $19.00 \pm 2.14$ & $34.17 \pm 7.82$ & 1.93 & 0.07 \\
$\quad$ aminotransferase & & & & \\
Calcium & $3.46 \pm 0.11$ & $3.63 \pm 0.24$ & 0.70 & 0.50 \\
Magnesium & $1.47 \pm 0.04$ & $1.43 \pm 0.05$ & 0.54 & 0.60 \\
Phosphorus & $2.44 \pm 0.14$ & $2.57 \pm 0.25$ & 0.48 & 0.64 \\
Total protein & $45.75 \pm 1.45$ & $42.83 \pm 2.89$ & 0.97 & 0.35 \\
Triglycerides & $2.37 \pm 0.47$ & $2.60 \pm 0.76$ & 0.27 & 0.79 \\
Cholesterol & $10.70 \pm 0.58$ & $11.60 \pm 0.93$ & 0.86 & 0.41 \\
\hline
\end{tabular}

ride and sodium followed a similar trend with values lower for telemetered fish than controls. When freshwater fish are exposed to stress, they typically lose ions (Wendelaar-Bonga 1997). Although we did not measure osmolality in this study, it may have provided a more integrative assessment of the ionic status of the fish. Nonetheless, we have little statistical evidence to support the notion that there was a long-term negative consequence of transmitters or the surgical procedure on wild largemouth bass.

Aspartate aminotransferase is an indicator of tissue damage (Wagner \& Congleton 2004, Morrissey et al. 2005), and we saw no differences between the telemetered and non-telemetered fish, or between telemetered fish with a 'good' incision condition and those after 8 to $10 \mathrm{~h}$ in laboratory environments (see Wendelaar-Bonga 1997), suggesting that there is no residual or increased stress for fish associated with carrying a telemetry device for several years. We had reasonable sample sizes, and only one of the parameters (i.e. potassium) approached significance after Bonferroni correction. If we were to interpret our data without using the Bonferroni correction (i.e. $\alpha=0.05$ ), only potassium would differ significantly. Potassium levels averaged $3.24 \mathrm{mmol} \mathrm{l}^{-1}$ for the control fish and $2.04 \mathrm{mmol}$ $\mathrm{l}^{-1}$ for the telemetered fish (Table 2 ). In fact, both chlo-

Table 4. Micropterus salmoides. Regression of plasma physiological indicators as a function of days since tagging in recaptured fish with previous telemetry implantations $(\mathrm{n}=14)$ and regression of plasma physiological indicators as a function of tag mass as a \% of fish body mass at the time of tagging in recaptured fish with previous telemetry implantations $(n=14)$. No significant differences were found for any parameters after Bonferroni corrections $(\alpha=0.0045)$

\begin{tabular}{|lcccc|}
\hline $\begin{array}{l}\text { Physiological } \\
\text { parameter }\end{array}$ & \multicolumn{3}{c}{$\begin{array}{c}\text { Statistics since } \\
\text { tagging }(\mathrm{d})\end{array}$} & \multicolumn{2}{c|}{$\begin{array}{c}\text { Statistics for tag } \\
\text { mass }\end{array}$} \\
& $\mathrm{R}^{2}$ & $\mathrm{p}$ & $\mathrm{R}^{2}$ & $\mathrm{p}$ \\
& & & & \\
\hline Glucose & 0.00 & 0.94 & 0.07 & 0.36 \\
Chloride & 0.00 & 0.93 & 0.10 & 0.26 \\
Sodium & 0.26 & 0.06 & 0.03 & 0.54 \\
Potassium & 0.00 & 0.92 & 0.04 & 0.48 \\
Aspartate & 0.09 & 0.29 & 0.02 & 0.66 \\
aminotransferase & & & & \\
Calcium & 0.00 & 0.81 & 0.01 & 0.77 \\
Magnesium & 0.00 & 0.85 & 0.20 & 0.17 \\
Phosphorus & 0.06 & 0.39 & 0.04 & 0.51 \\
Total protein & 0.09 & 0.30 & 0.02 & 0.62 \\
Triglycerides & 0.03 & 0.57 & 0.02 & 0.61 \\
Cholesterol & 0.10 & 0.26 & 0.31 & 0.04 \\
\hline
\end{tabular}

with a 'poor' incision condition. Moreover, we saw no evidence of transmitter expulsion. These results are contrary to previous studies where expulsion of tags has occurred during shorter time intervals (e.g. weeks to months; Lucas 1989), which suggests that transmitter expulsion is a species-specific phenomenon and not applicable to largemouth bass. Our results also suggest that despite the physical appearance of the incision, evidence of pressure necrosis or retained sutures is not associated with significant tissue damage detectable using routine physiological techniques (e.g. aspartate aminotransferase analysis).

Blood-borne physiological indicators can be useful in determining the nutritional condition of fish (e.g. Congleton \& Wagner 2006, Hanson \& Cooke in press). The similarity in calcium, magnesium, phosphorus, total protein, triglycerides, and cholesterol levels between the 2 groups suggests that there is no change in food intake or nutritional condition for fish that were implanted with a telemetry device and carried it for extended periods. The control group of fish are expected to exhibit normal, healthy feeding behaviours, and from this study, transmitter-implanted fish appear to exhibit the same pattern as revealed by their nutritional physiology. Previous research has revealed that these indicators are sensitive to changes in food intake and activity in wild largemouth bass (Hanson \& Cooke in press).

We must caution that the physiological data reflect the condition of the animals that were re-captured and that these may not be representative of the sample that were originally tagged. For example, it is possible that some fish that may have been in poorer condition might have died and thus been unavailable for recap- 
ture. Alternatively, if fish in poorer condition changed their feeding behaviour then they may have been less vulnerable to the sampling technique. Future experiments could consider collecting a blood sample at the time of tagging and evaluating the nutritional physiology at the time of capture relative to fate (survival, behaviour; see Cooke et al. 2005b). Nonetheless, sampling moribund fish immediately prior to death remains a challenge for field physiologists.

\section{Surgical techniques}

Proper surgery techniques and equipment are essential to maintaining fish health and welfare (Mulcahy 2003). From the detailed observations made during this study (Table 1), the majority of incision sites were well healed. We can therefore conclude that surgery techniques and tools used during this study were adequate and caused minimal harm to fish health. However, even limited incidence of retained sutures and pressure necrosis highlights the need to modify materials and techniques when conducting surgery on fish to ensure no long-term impacts on fish condition and welfare. Indeed, we noted that some absorbable sutures were retained for a minimum of $362 \mathrm{~d}$, suggesting that not all absorbable sutures degrade in a reasonable time period following surgery. Moreover, pressure necrosis was evident in almost one-third of our recaptured fish, even when using tags that weighed as little as $10 \mathrm{~g}$ and represented $1.9 \%$ of the mass of the fish (on average; range: 0.84 to $3.59 \%$ ). Typically, the mass of transmitters used in fish surgeries is kept close to $2 \%$ of the mass of the fish (Winter 1983, Jepsen et al. 2002), although there is some evidence that in the short term, larger ratios are acceptable (e.g. Brown et al. 1999, Jepsen et al. 2004). Clearly, the current study revealed that even tags weighing $\sim 2 \%$ of the body weight of the fish can cause pressure necrosis in the long term, so all efforts should be made to use the smallest tag (mass and volume) possible. When conducting surgery, a variety of factors come into play, such as appropriate fish size, tag selection, anaesthesia, disinfectants, suture material, technique, and recovery time. These factors have been studied to determine which are most effective in maintaining overall fish health in the short term (Bridger \& Booth 2003, Mulcahy 2003, Wagner \& Cooke 2005). However, there still remain many opportunities for evaluating the long-term consequences of these different factors on wild fish of different species inhabiting different environments. The main goal of telemetry is to allow researchers to observe fish with as little impact on their normal behaviour and physiology as possible (Bridger \& Booth 2003). By ensuring that surgeons are properly trained and educated, and that techniques are consistent across a study, researchers have a greater chance of attaining this goal (Cooke \& Wagner 2004).

\section{CONCLUSIONS}

As telemetry becomes an increasingly popular tool in fisheries research, it is important to test the impacts of these devices on wild populations in the long-term to allow researchers and managers to validate the data obtained from these studies. The results of this study are important to fisheries managers to validate the use of transmitters as a tool to collect a variety of data from fish species while having a minimum impact. Our results show that telemetry devices have little impact on overall fish health and condition, and thus are likely not altering the behaviour monitored with these transmitters. However, the observations of some retained sutures and pressure necrosis indicate that proper surgical practices and materials are critical, and surgeons are encouraged to consult current literature on proper techniques and tools to maintain consistency and ensure that animal welfare is top priority. Clearly more research is needed on the selection of appropriate suture materials for different species and environments, as a result of differences in the physical and chemical properties of the bodies of fish and the surrounding water. There is also need for further studies on the condition and fate of fish that have been carrying transmitters in the wild for long time periods as tag life continues to be extended such that animals may be burdened with a transmitter for $10+$ yr or their entire life. Such information will reveal the extent to which long-term data from telemetry studies are robust and the extent to which the telemetry devices are affecting fish welfare and condition.

Acknowledgements. We thank the Warner Lake Research Consortium including D. Philipp (Illinois Natural History Survey), G. Niezgoda (Lotek Wireless), and C. Suski (University of Illinois) who enabled the implantation of these fish. The Ontario Ministry of Natural Resources provided scientific collection permits, and the Canadian Council on Animal Care approved the research project. We thank N. Jepsen and 2 anonymous referees for providing valuable comments on the manuscript. Funding for this research was provided by a Fisheries Research grant to C.M.O. from the Ontario Federation of Anglers and Hunters and by an NSERC grant to S.J.C.

\section{LITERATURE CITED}

Adams NS, Rondorf DW, Evans SD, Kelly JE (1998) Effects of surgically and gastrically implanted radio transmitters on growth and feeding behaviour of juvenile Chinook salmon. Trans Am Fish Soc 127:128-136 
Bridger CJ, Booth RK (2003) The effects of biotelemetry transmitter presence and attachment procedures on fish physiology and behaviour. Rev Fish Sci 11:13-34

Brown RS, Cooke SJ, Anderson WJ, McKinley RS (1999) Evidence to challenge the ' $2 \%$ rule' for biotelemetry. N Am J Fish Manag 19:867-871

> Close DA, Fitzpatrick MS, Lorion CM, Li HW, Schreck CB (2003) Effects of intraperitoneally implanted radio transmitters on the swimming performance and physiology of pacific lamprey. N Am J Fish Manag 23:1184-1192

Congleton JL, Wagner T (2006) Blood-chemistry indicators of nutritional status in juvenile salmonids. J Fish Biol 69: 473-490

> Cooke SJ (2008) Biotelemetry and biologging in endangered species research and animal conservation: relevance to regional, national, and IUCN Red List threat assessments. Endang Species Res 4:165-185

Cooke SJ, Wagner GN (2004) Training, experience, and opinions of researchers who use surgical techniques to implant telemetry devices into fish. Fisheries 29:10-18

Cooke SJ, Graeb BDS, Suski CD, Ostrand KG (2003) Effects of suture material on incision healing, growth and survival of juvenile largemouth bass implanted with miniature radio transmitters: case study of a novice and experienced fish surgeon. J Fish Biol 62:1360-1388

Cooke SJ, Hinch SG, Wikelski M, Andrews RD, Wolcott TG, Butler PJ (2004) Biotelemetry: a mechanistic approach to ecology. Trends Ecol Evol 19:334-343

Cooke SJ, Niezgoda G, Hanson KC, Suski CD, Tinline R, Philipp DP (2005a) Use of CDMA acoustic telemetry to document 3-D positions of fish: relevance to the design and monitoring of aquatic protected areas. Mar Technol Soc J 39:17-27

Cooke SJ, Crossin GT, Patterson D, English K and others (2005b) Coupling non-invasive physiological and energetic assessments with telemetry to understand inter-individual variation in behaviour and survivorship of sockeye salmon: development and validation of a technique. J Fish Biol 67:1342-1358

Feldhaus JW, Heppell SA, Mesa MG, Li HW (2008) Hepatic heat shock protein 70 and plasma cortisol levels in rainbow trout after tagging with a passive integrated transponder. Trans Am Fish Soc 137:690-695

Hanson KC, Cooke SJ (in press) Nutritional condition and physiology of paternal care in two congeneric species of black bass (Micropterus spp.) relative to stage of offspring development. J Comp Physiol B

> Hanson KC, Cooke SJ, Suski CD, Niezgoda G, Phelan FJS, Tinline R, Philipp DP (2007a) Assessment of largemouth bass (Micropterus salmoides) behaviour and activity at multiple spatial and temporal scales utilizing a whole-lake telemetry array. Hydrobiologia 582:243-256

Hanson KC, Cooke SJ, Suski CD, Niezgoda G and others (2007b) Monitoring bass behaviour in real time over a three year period: implications for conservation and management. In: Kerr SJ (ed) Bass research and management in Ontario II. Proceedings. Ontario Ministry of Natural Resources, Peterborough, ON, p 23-31

Hasler CT, Hanson KC, Cooke SJ, Tinline R and others (2007) Frequency, composition and stability of associations among individual largemouth bass (Micropterus salmoides) at diel, daily, and seasonal scales. Ecol Freshw Fish 16:417-424

Huntingford FA, Adams CE, Braithwaite VA, Kadri S, Pottinger TG, Sandoe P, Turnbull JF (2006) Current issues in fish welfare. J Fish Biol 68:332-372
Jepsen N (2003) Long-term retention of radio transmitters in pikeperch (Stizostedion lucioperca). J Fish Biol 63: 260-262

Jepsen N, Aarestrup K (1999) A comparison of the growth of radio-tagged and dye-marked pike. J Fish Biol 55: 880-883

> Jepsen N, Davis LE, Schreck CB, Siddens B (2001) The physiological response of Chinook salmon smolts to two methods of radio tagging. Trans Am Fish Soc 130: 495-500

> Jepsen N, Koed A, Thorstad EB, Baras E (2002) Surgical implantation of telemetry transmitters in fish: how much have we learned? Hydrobiologia 483:239-248

Jepsen N, Schreck C, Clement S, Thorstad E (2004) A brief discussion of the $2 \% \mathrm{tag} / \mathrm{bodymass}$ rule. In: Spedicato MT, Marmulla G, Lembo G (eds) Aquatic telemetry: advances and applications. FAO - COISPA, Rome, p 255-259

Jepsen N, Mikkelsen JS, Koed A (2008) Effects of tag and suture type on survival and growth of brown trout with surgically implanted telemetry tags in the wild. J Fish Biol 72:594-602

> Lower N, Moore A, Scott AP, Ellis T, James JD, Russell IC (2005) A non-invasive method to assess the impact of electronic tag insertion on stress levels in fish. J Fish Biol 67: 1202-1212

> Lucas MC (1989) Effects of implanted dummy transmitters on mortality, growth, and tissue reaction in rainbow trout, Salmo gairdneri Richardson. J Fish Biol 35:577-587

Lucas MC, Baras E (2000) Methods for studying spatial behaviour of freshwater fishes in the natural environment. Fish Fish 1:283-316

Martinelli TL, Hansel HC, Shively RS (1998) Growth and physiological responses to surgical and gastric radio transmitter implantation techniques in subyearling Chinook salmon (Oncorhynchus tshawytscha). Hydrobiologia 371372:79-87

Moore A, Russell IC, Potter ECE (1990) The effects of intraperitoneally implanted dummy acoustic transmitters on the behaviour and physiology of juvenile Atlantic salmon, Salmo salar. J Fish Biol 37:713-721

Morrissey MB, Suski CD, Esseltine KR, Tufts BL (2005) Incidence and physiological consequences of decompression in smallmouth bass after live-release angling tournaments. Trans Am Fish Soc 134:1038-1047

Mulcahy DM (2003) Surgical implantation of transmitters into fish. ILAR J 44:295-304

Tyus HM (1988) Long-term retention of implanted transmitters in Colorado squawfish and razorback sucker. N Am J Fish Manag 8:264-267

Wagner T, Congleton JL (2004) Blood-chemistry correlates of nutritional condition, tissue damage, and stress in migrating juvenile Chinook salmon Oncorhynchus tshawytscha. Can J Fish Aquat Sci 61:1066-1074

- Wagner GN, Cooke SJ (2005) Methodological approaches and opinions of researchers involved in the surgical implantation of telemetry transmitters in fish. J Aquat Anim Health 17:160-169

Wendelaar-Bonga SE (1997) The stress response in fish. Physiol Rev 77:591-625

Winter JD (1983) Underwater biotelemetry. In: Nielsen LA, Johnson DL (eds) Fisheries techniques. American Fisheries Society, Bethesda, MD, p 371-395

Zar JH (1999) Biostatistical analysis, 4th edn. Prentice-Hall, Englewood Cliffs, NJ 